\title{
Outsourcing and Freelancing as Modern Labor Market Trends: Professional Requests of Youth
}

\author{
Irina A. Donina 1[ORCID 0000-0002-8191-196X], \\ Svetlana N. Vodneva ${ }^{2 *[O R C I D ~ 0000-0002-1760-6151], ~}$ \\ Tatyana E. Klets 2[ORCID 0000-0001-8857-1569], \\ Irina A. Dagaeva 2[ORCID 0000-0003-4006-1556], \\ Ekaterina E. Donina 1[ORCID 0000-0002-5447-2148]
}

\author{
${ }^{1}$ Yaroslav-the-Wise Novgorod State University, Veliky Novgorod, Russia \\ ${ }^{2}$ Pskov State University, Pskov, Russia \\ wodnewa@yandex.ru
}

\begin{abstract}
The modern period of development of the Russian economy is undergoing a transformation process due to globalization and informatization and is characterized by the development of flexible forms of network interaction between actors of economic relations, close information links, the development of international trade and investment, participation in the international division of labor. These trends lead to the emergence of nontraditional forms of interaction in the business community. Outsourcing and freelancing as forms of employment based on temporary contracts, part-time employment, and self-employment are among the dynamically developing trends in the labor market. In this regard, the identification of the features of outsourcing and freelancing as socio-economic phenomena is of certain relevance. The article examines the essential characteristics of these forms of economic relations, defines their features in comparison with traditional forms of labor relations, identifies the positive aspects and possible risks of their use. Some trends in the development of outsourcing and freelancing which contribute to their wide distribution in the Russian business reality and make them in demand among young people - university graduates - have been found. To identify professional needs of students as future actors of economic activity, the authors of the study have conducted a survey among students of various areas of study of bachelor programs, aimed at identifying students' plans for building a future career, self-assessment of the degree of development of their personal and professional qualities necessary for successful professional realization. The results obtained can become guidelines for employers in choosing mechanisms for managing their organization and personnel in accordance with the trends in the professional interests of young people, and for future specialists planning to choose outsourcing or freelancing and assessing the benefits and risks of such work options.
\end{abstract}

Keywords: outsourcing, university graduate, professional self-determination, labor market, labor relations system, freelance

\section{INTRODUCTION}

The economy of modern Russia is characterized by the introduction of advanced management mechanisms for all production processes capable of increasing the competitiveness of domestic enterprises.

Among the dynamically developing models of employment today, one can single out outsourcing and freelancing which are introduced into practice by business leaders and are used by the economically active population.
The demand for outsourcing as a tool for business management and freelancing as a form of self-employment is facilitated by the intensive development of information and communication technologies and the digitalization of all spheres of the economy, ensuring the guaranteed transfer of large volumes of information between companies, which becomes relevant during the spread of COVID-19 and the use of new forms of personnel management in companies. These non-standard forms of employment are becoming a kind of marker of the information society. 
Obviously, in order to be competitive in the market today, the head of the enterprise directs efforts to improve the efficiency of the business entity. Outsourcing, as one of such market instruments, allows one to rationally build a business system. A freelancer or a remote worker can also become an outsourcer. According to foreign researchers G. Opait, D. Damian, A. Capatina, freelancing is a special type of entrepreneurship [1] which, according to T. Gries, W. Naude, should be more widely used in outsourcing, which will contribute to structural changes associated with the expansion of the specialization of an organization, an increase in employment and labor productivity [2]

The outlined departure from traditional business models actualizes the problem of a comprehensive study of these innovative forms of labor relations. An analysis of the scientific literature on the problem of the research has revealed the etymology of the concepts of outsourcing and freelancing.

Most scientists define outsourcing as the transfer on a contractual basis of some non-core business processes to be serviced by a third-party company specializing in this particular area and having the appropriate knowledge, experience, and technical means [3-5]. The term outsourcing came from the United States and became entrenched in the business vocabulary in the $1970-80$ s. In the $21^{\text {st }}$ century, outsourcing is rapidly developing and becoming an independent type of economic activity since it contributes to the strengthening of the division and cooperation of labor in modern conditions. According to experts, the number of outsourcing contracts in the world annually increases by $15-20 \%$ and their cost increases by $25-30 \%$ [6].

One of the future trends may become the distributed enterprise model which makes it possible to improve interaction with customers and partners and enhance the process of coordinating work on a product. These trends are consistent with such an innovative form of work organization as freelancing which is gaining more and more popularity among young professionals belonging to the generation that has grown up in the era of global digitalization [7].

In modern labor economics, freelancing is defined as a form of self-employment focused on the actual completion of contractual work. Studies of this model of employment indicate that freelancing is a unique form of manifestation of economic activity of the population, which allows one to earn money from the work one wants to do, to get away from routine traditional work, and also to limit the costs of starting one's own business [8-10].
Analysis of the state of scientific knowledge on the problem of outsourcing and freelancing development allows us to state that at present there is a fairly large amount of research on assessing the economic efficiency of these forms of labor relations, however, despite a significant number of articles by foreign and domestic scientists on this topic, the issue of professional expectations and the readiness of graduates of Russian universities for professional activities as freelancers or as part of an outsourcing company cannot be considered fully studied. In this regard, the research conducted by the authors of this article is relevant since it introduces additional information into the understanding of the problems of youth employment and their successful adaptation to the modern labor market.

The scientific novelty of the research lies in identifying the essential characteristics, advantages, and possible risks of using outsourcing and freelancing in domestic practice, as well as in analyzing the degree of willingness of future university graduates to use these forms of employment.

\section{MATERIALS AND METHODS}

The purpose of this study is to explore the characteristics of outsourcing and freelancing as modern trends in the labor market in the context of professional requests of undergraduate students as future actors of industrial relations. Within the framework of the study, the following tasks have been solved:

1) content analysis of the concepts of outsourcing and freelancing, identification of their essential characteristics, and determination of the advantages and possible risks of using these forms of employment;

2) conducting a survey aimed at identifying the professional preferences of undergraduate students regarding their future professional activities;

3) interpretation of the obtained empirical data in the context of their relationship with the specifics of outsourcing and freelancing.

The study has used methods of analysis and systematization of foreign and domestic sources on the topic of the problem under consideration; content analysis of the concepts of outsourcing and freelance. The empirical base of the research was made up of a survey in the form of a questionnaire, statistical analysis, and 
interpretation of the results of the questionnaire survey of students.

The conducted analytical study of outsourcing as a phenomenon of the modern economy allows us to speak about the strengthening of its effectiveness in domestic practice in the long term. Experts point out several factors forcing companies to switch to outsourcing. According to I. Donina and E. Vovk, the main ones are high competition and a shortage of resources. In the presence of many competitors, the company needs to look for opportunities to optimize its costs, save time, resources, and focus on solving key business problems [11].

Today the industry spectrum of outsourcing is quite wide. Among the outsourced functions, the following services are leading: information systems support $(75 \%$ of IT service corporate consumers opt for outsourcing), HR management, personnel recruitment and training, $\mathrm{PR}$ and advertising services, cleaning services, security and safety services, organization of transportation and logistics, administrative support, marketing and sales, accounting, etc. According to experts, outsourced performers are successfully filling the shortage of personnel in many industries, associated with the general aging of the working population, a decrease in interest in working professions on the part of young people. Almost a third of the proposals (30\%) are addressed to young professionals without work experience. In addition, every tenth vacancy involves a remote work format (21\%) [12].

Labor transformations have contributed to the development of freelancing as a new employment model. Many outsourcing companies actively use the services of freelancers in a situation where there is a lucrative deal, and the required specialist is not on the staff. The most demanded freelance services are programming, web design, copywriting, article and research papers writing, advertising, marketing, language training and translation/interpretation, audio/video and music processing. Thus, it is clear that the above services in the form of freelancing are very attractive for young people since it is this age group that successfully masters advanced technologies, acquires professional experience, demonstrating entrepreneurial attitude and creativity.

Comparative analysis of the positive and negative features of outsourcing and freelancing, presented in Table 1 helps to make a more detailed correlation of these characteristics and professional requests of young people.

Table 1. Comparative analysis of the advantages and risks of outsourcing and freelancing

\begin{tabular}{|c|c|}
\hline ing & \\
\hline \multicolumn{2}{|c|}{ Advantages } \\
\hline \multirow{3}{*}{$\begin{array}{l}\text { For employers: } \\
\text { - concentration on the main business processes by } \\
\text { delegating non-core functions to an outsourcer; the ability to } \\
\text { respond flexibly and adapt to changes in the service market; } \\
\text { - reduction of production costs; saving on payments to an } \\
\text { external service provider in comparison with the costs of } \\
\text { maintaining and training in-house specialists; } \\
\text { - simplifying the structure of the organization, increasing the } \\
\text { operational efficiency of the business, and increasing the } \\
\text { investment attractiveness of the company; } \\
\text { - the ability to remain in the status of a small enterprise while } \\
\text { keeping additional advantages of this form of ownership; } \\
\text { - improving the quality of the products obtained through the } \\
\text { use of advanced technologies and the accumulated } \\
\text { experience of specialized companies; } \\
\text { - a simplified procedure for terminating the contract in case } \\
\text { of poor-quality services. }\end{array}$} & For em \\
\hline & $\begin{array}{l}\text { nly for the work performed, the possibility of } \\
\text { ooperate without complicated legal procedures; } \\
\text { lity of attracting highly qualified specialists from } \\
\text { f costs due to the reduction of jobs in the office } \\
\text { ence of the need to provide a freelance worker } \\
\text { uarantees; } \\
\text { of the tax burden; facilitation of document } \\
\text { t. }\end{array}$ \\
\hline & $\begin{array}{l}\text { flexible working } \\
\text { bility with main w } \\
\text { potential custome } \\
\text { ers at the same tim } \\
\text { high level of incom }\end{array}$ \\
\hline \multicolumn{2}{|c|}{ Risks } \\
\hline \multirow{2}{*}{$\begin{array}{l}\text { For employers: } \\
\text { - the possibility of information leakage, loss of confidentiality } \\
\text { and business security; } \\
\text { - the risk of a change in the cost of a service when the state } \\
\text { of the market changes; } \\
\text { - lack of control and management over the actions of the } \\
\text { outsourcer on the part of the customer of services; poor- } \\
\text { quality outsourcing services and the possibility of breaking } \\
\text { contractual relations; } \\
\text { - non-compliance with the terms of the contract by the } \\
\text { parties; limited ability to quickly change the terms of the } \\
\text { contract for the provision of services. }\end{array}$} & $\begin{array}{l}\text { erring the order } \\
\text { ontrolling the orde }\end{array}$ \\
\hline & $\begin{array}{l}\text { n, search for orders; } \\
\text { untering an unscrupulous customer; } \\
\text { benefits package, career growth, and social } \\
\text { vithin a team; } \\
\text { constant professional growth and mobile } \\
\text { ges in the labor market; } \\
\text { me. }\end{array}$ \\
\hline
\end{tabular}

Source: Compiled by the authors 
Thus, the advantages of outsourcing and freelancing services are quite strong, which increases their demand in the labor market. As a result, they allow reducing the operating costs of companies and open access to employment for specialists who are unwilling or unable to get a permanent job in the current situation.

However, the use of these employment tools entails several risks. Therefore, companies should clearly understand which functions it is more expedient to delegate to an external contractor; it is also necessary to develop mechanisms for relations among outsourcing and freelance participants, ensure legal regulation of these forms of economic relations, and create an up-to-date regulatory framework.

To identify the professional interests and career plans of students as future job-seekers in the labor market, the authors of the study have conducted a survey, in which 103 students of various areas of study of bachelor programs (future teachers, vehicle service specialists, technologists of artistic processing of materials, agricultural engineers, journalists, artists, etc.) of Pskov State University (Pskov) and Yaroslav-the-Wise Novgorod State University (Veliky Novgorod) took part.

The respondents answered several questions, including the following: do you plan to work in your chosen specialty, what form of employment is preferable for you (traditional employment, freelancing, outsourcing). It was proposed to identify attractive working conditions, work schedule, personal and professional qualities necessary for successful work, as well as factors that may hinder the implementation of the professional plans of the respondents.

\section{RESULTS}

According to the results of the survey, $48 \%$ of the respondents plan to work in their chosen specialty, while $10 \%$ do not want to work in the specialty for which they are being trained, and $42 \%$ of the respondents have not yet decided.

Students who do not plan to pursue the occupations for which they will be qualified in the future prefer to realize themselves in entrepreneurship (32\%), information sphere (16\%), sports $(12 \%)$, food industry (10\%), education (10\%), culture $(6 \%)$, design $(4 \%)$, advertising (4\%), Internet technologies, mechanical engineering, translation/interpretation, the fashion industry $(6 \%)$.
Thus, it is the spheres characteristic of freelancing and outsourcing that are attractive to young people.

For the majority of the respondents, namely $38 \%$, individual entrepreneurship is the most preferred type of activity in the future, $34 \%$ of the respondents are in favor of freelancing. Only $18 \%$ of them plan to get a regular job in a company. We can conclude that future university graduates would like to pursue independent labor activities (Figure 1).

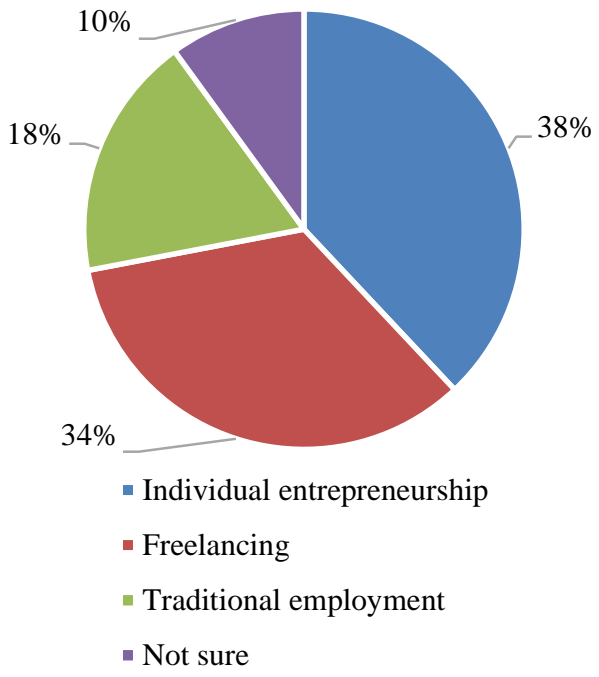

Figure 1. Most preferred activity in the future Source: Compiled by the authors

Among the most attractive features of freelancing, the following were highlighted: flexible hours, work for oneself, the ability to work remotely, the possibility of self-realization and the choice of an interesting job for oneself, the absence of dependence on the management. Among the negative aspects of freelancing, the following were mentioned: the risk of going bankrupt, not finding clients, having poor time management, facing fraud, instability of earnings and orders, difficulty in motivating oneself, creative burnout, the need to independently purchase equipment, the complexity of an independent start, high competition, lack of social package. These shortcomings indicate that students realistically assess the possible risks of freelancing and are aware of the need to comply with certain conditions including self-organization, a convincing professional portfolio, and quick response to changes in virtual labor exchanges.

The respondents see such factors as the stability of the schedule, place of work, and wages, career opportunities, responsibility distribution, discipline, social support from the state, and confidence in the future as positive in permanent employment. 
Considering traditional employment, the respondents singled out such negative aspects as an inflexible work schedule, a fixed salary, subordination to bosses, a lack of creativity and self-realization, and strict requirements.

The preferred mode of work for the majority $(58 \%)$ of the respondents is having no fixed office hours, which meets the conditions of work in an outsourcing company or as a freelancer (Figure 2).

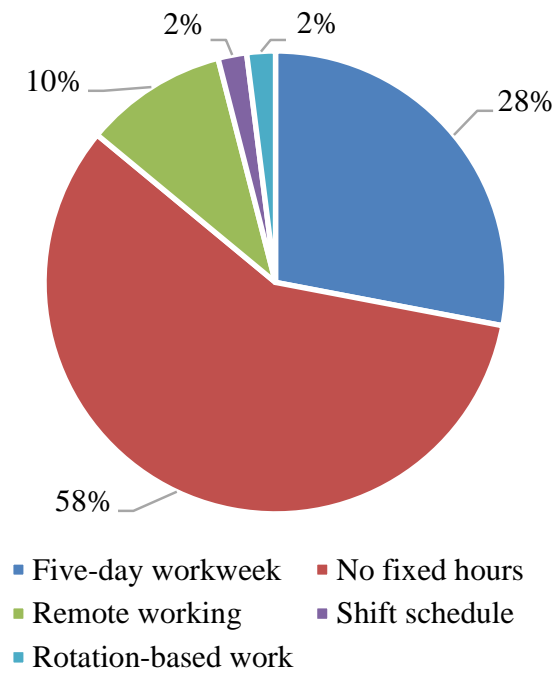

Figure 2. Preferred mode of work

Source: Compiled by the authors

Among the most significant factors hindering the implementation of the professional plans of the respondents, the following were highlighted: increased personal anxiety (56\%), the inability to realize themselves in the place of permanent residence $(46 \%)$, low wages in the chosen profession $(56 \%)$, deflated or inflated self-esteem (34\%), lack of start-up capital (32\%) or jobs in the specialty (28\%).

The most important business and personal qualities necessary for building a successful career, according to the respondents, are the following: the ability to effectively interact with people $(82 \%)$, high professional competence (72\%), stress resistance $(66 \%)$, dedication $(66 \%)$, efficiency and striving for personal and professional growth $(62 \%$ each).

Based on self-esteem, the respondents have the following qualities as best formed: the ability to interact with people (56\%), dedication (32\%), efficiency (32\%). Time management is insufficiently formed (only $12 \%$ of the respondents chose it as a formed quality).

In matters of professional development, preference is given to advanced training courses in the chosen field of activity (42\%), traditional employment and the acquisition of practical experience $(18 \%)$, the implementation of their entrepreneurial idea (14\%), obtaining an additional profession (12\%), which is reflected in Figure 3. This choice of the respondents indicates an active position in matters of professional advancement even during their studies.

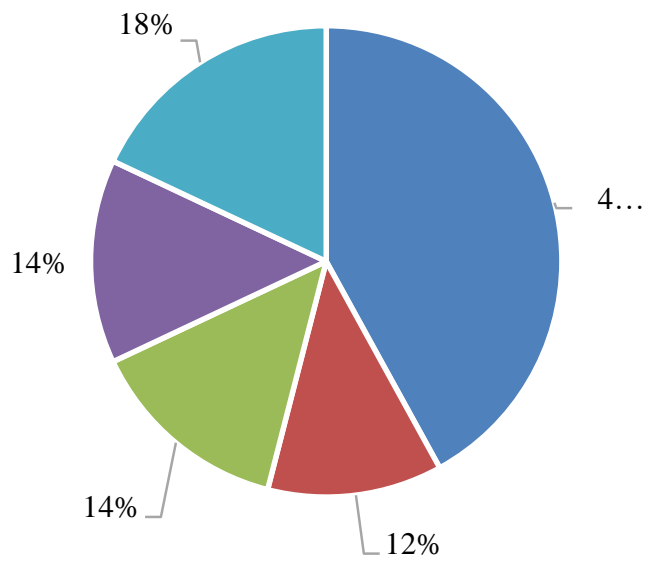

- Maintain professional competence through continuing professional development

- Obtain an additional profession

- Have full-time employment, gradually climbing the career ladder

- Become an entrepreneur and work only for yourself

- Combine professional activities

Figure 3. Professional development activities Source: Compiled by the authors

The survey conducted among undergraduate second-, third-, and fourth-year students has revealed a prospective view of young people on building their future career, their level of social wellbeing, and an idea of success in life.

\section{DISCUSSION}

The study has made it possible to draw up a portrait of a future participant in the labor market. This is a highly qualified professional with a higher education who effectively interacts with people, which allows them to be an individual entrepreneur or a freelancer and opens up the possibility of free regulation of their work and leisure in the process of independent organization of their professional activities. However, the study has revealed that, despite the preference for independence in future work activities and the desire to pursue their personal goals, young people are not always ready to correlate their priorities in life, they experience difficulties with self-organization and time 
management, do not have a sufficient level of stress resistance and risk appetite.

Owing to the prevailing advantages and popularity among potential actors of labor relations, outsourcing and freelancing can become effective tools for attracting young people to perform labor functions and acquire professional skills, while not being tied to one organization to perform their job duties. In turn, the employer also needs to adapt to the changing conditions of the labor market, use new types of motivation, make changes in the organization of work in terms of the working mode of different categories of employees and, as on a testing platform, make wider use of the possibilities of the above innovative forms of labor relations.

Thus, it can be stated that the problematic field of research related to the spread and demand for such forms of modernization of economic activity as outsourcing and freelancing is wide enough and should include the study of not only economic but also social aspects of the above forms of labor relations.

\section{CONCLUSION}

In conclusion, the study of modern trends in the labor market indicates that currently there are new forms of employment which can to the greatest extent meet the needs of all actors of economic relations, in particular, outsourcing is a productive mechanism for improving the activities of companies, strengthening their competitive advantage. Freelancing, as a popular selfemployment model, especially among young independent professionals, is also an emerging form of modernization of economic activity.

These changes are reflected in the state of the labor market, changing the demand and supply of labor, expanding the list of its participants, and introducing new ways of attracting and/or hiring workers. Therefore, a potential employer needs to determine on what conditions they are ready to meet their staffing needs, what motivational mechanisms should be used to attract professional, creatively thinking, and promising young specialists focused on individualizing their work biography.

The research results have a certain practical significance and can be used in further socioeconomic study since the identified trends in the modern labor market, manifested in the intensive dissemination of such business models as outsourcing and freelancing, give rise to the transition to the design and development of specific measures to promote successful adaptation and selfrealization of young people in the face of uncertainty and volatility of the modern labor market.

In our opinion, taking into account the requests and interests of young people, one of the effective measures to solve the above problems can be the integration of special courses into the curricula of university disciplines aimed at forming students' holistic understanding of modern forms of employment, including freelancing and outsourcing, their advantages and disadvantages. More active communication with potential employers in the training process will also contribute to the confident behavior of graduates in the labor market.

\section{AUTHORS' CONTRIBUTIONS}

The authors made an equal contribution to the study: collection and analysis of material; definition of goals and objectives, research methods; formulation and scientific substantiation of conclusions, registration of key research results in the form of an article.

\section{REFERENCES}

[1] G. Opait, D. Damian, A. Capatina, "Freelancer as an entrepreneur: a choice as career development", Marketing and Management of Innovations, 2019, vol. 3, pp. 327-340. DOI: 10.21272/mmi.2019.3-25

[2] T. Gries, W. Naude, "Entrepreneurship and structural economic transformation", Small Business Economics, 2010, vol. 1(34), pp. 1329. DOI: $10.1007 / \mathrm{s} 11187-009-9192-8$

[3] J.B. Haywood, "Autsorsing: in search of competitive advantages", Moscow: Williams Publishing House, 2004, 176 p. (In Russ.).

[4] M.V. Dubrova, N.A. Guz, N.N. Zhilina, "ITOutsourcing as a form of capital concentration in the digital economy environment", In Proceedings of ISPC GCPMED 2018 "Global Challenges and Prospects of the Modern Economic Development": The European Proceedings of Social \& Behavioural Sciences, 2019, vol. 59, pp. 192-198. DOI:10.15405/epsbs.2019.03.20

[5] M.N. Pevzner, R.M. Sheraizina, I.A. Donina, P.A. Petryakov, N.V. Aleksandrova, "Marketing-related activity in a heterogeneous educational organization", Espacios, 2017, vol. 38(40), p. 29. 
[6] I.A. Dagaeva, O.S. Feoktistova, A.V. Proskurina, "The practice of implementing youth policy in the constituent entities of the Russian Federation in the context of increasing the level of youth self-realization", In Proceedings of ISPC "Russia 2020 - a new reality: economy and society": Atlantis Press, 2021, pp. 321-325. DOI: 10.2991/aebmr.k.210222.063

[7] N. Kuzhanova, T. Klets, "Methodological and psychological aspects of education for sustainable development in Russia with regard to international cooperation", In Proceedings of the 11th ISPC "Vide. Tehnologija. Resursi Environment. Technology. Resources", 2017, vol. 1, pp. 165-168. DOI: $10.17770 /$ etr2017vol1.2559

[8] C.S. Hüseyin, A. Lütfihak, "The relationship between entrepreneurial characteristics and entrepreneurial intention", In Proceedings of the 13th International Strategic Management Conference: The European Proceedings of Social \& Behavioural Sciences, 2017, vol. 21, pp. 363-371. DOI: 10.15405/epsbs.2017.12.02.31

[9] N.I. Kuzhanova, A.M. Dementyev, T.E. Klets, "Formation of risk-balanced style of professional activity among university students", In Proceedings of the 12th ISPC "Vide. Tehnologija. Resursi - Environment, Technology. Resources", 2019, vol. 1. pp. 127130. DOI: $10.17770 /$ etr2019vol1.4034

[10] K.O. Latysheva, V.O. Borovikova, "Educational background as a factor of national welfare boosting", In Proceedings of WELLSO 2016: The European Proceedings of Social \& Behavioural Sciences, 2017, pp. 96-105. DOI: 10.15405/epsbs.2017.01.13

[11]I.A. Donina, E.V. Vovk, "Training staff of project teams for modern business", In Proceedings of ISPC MTSDT 2019 "Modern Tools for Sustainable Development of Territories. Special Topic: Project Management in the Regions of Russia": The European Proceedings of Social \& Behavioural Sciences, 2019, pp. 107-113. DOI: 10.15405/epsbs.2019.12.05.13

[12]M. Suzdalova, V. Lizunkov, E. Malushko, N. Sytina, V. Medvedev, "Innovative forms of partnership in development and implementation of university-business cooperation", In Proceedings of ISPC WELLSO 2016: The European Proceedings of Social \& Behavioural Sciences, 2017, pp. 450-455. DOI: 10.15405/epsbs.2017.01.61 